\title{
THE EFFECT OF RETURN ON ASSETS, FIRM SIZE, AND FINANCING TO DEPOSIT RATIO ON THE STOCK PRICE OF PT. BRI SHARIA, TBK.
}

\author{
Dadang Husen Sobana \\ Program Studi Manajemen Keuangan Syariah, \\ Fakultas Ekonomi dan Bisnis Islam, UIN SGD Bandung \\ dadanghusensobana@uinsgd.ac.id
}

\begin{abstract}
The stock price of PT BRI Shariah TBK since carrying out the IPO has continued to appreciate to 120 per cent, first the decision to merge three state-owned sharia banks into one Indonesian sharia bank in the last quarter of 2020. This study aims to analyze the various factors that affect the share price of PT BRI Shariah TBK during 2019-2020 based on ROE, Company Size, and FDR as variables that were thought to influence it. The study uses a descriptive method with a quantitative approach. The study uses secondary data obtained from the monthly publication reports and the monthly share price of PT. BRI Shariah, TBK, accessed from Yahoo Finance. Data analysis using multiple regression analysis, where the processing uses E-views 9 software. This study concludes that simultaneously ROE, Firm Size, and FDR have a significant effect on the stock price of PT. BRI Shariah TBK, Then partially ROE and FDR have a significant effect on the stock price of PT. BRI Shariah TBK in 2019 and 2020.
\end{abstract}

Keywords: ROE; Firm Size; FDR; Stock Price

\section{Introduction}

This research is motivated by the phenomenon of the price increase in shares of PT. BRI Shariah TBK by 19.61 percent at the time of the first transaction on the Indonesia Stock Exchange (IDX) or what is often called the Initial Public Offering (IPO). The IPO of BRI Shariah became the first for a sharia subsidiary owned by Badan Usaha Milik Negara (BUMN) in English is State-Owned Enterprises to take the floor on the stock exchange. The 64 percent increase in net profit in the first quarter of 2018 also supported the IPO decision.

BRI Shariah's decision as a sharia issuer is fully supported by the public. This can be seen in stock transactions that have shot up since the announcement of the merger of Indonesian Islamic banks, then in October 2020 share prices have increased sharply by 120 percent since the IPO. Even though in 2019, BRI Shariah experienced a decline in financial performance. Until September 2019, BRI Shariah's net profit

Received: 2020-12-30 | Reviced: 2021-06-03 | Accepted: 2021-06-30

Indexed : Sinta, DOAJ, Garuda, Crossref, Google Scholar|DOI: 10.29313/amwaluna.v5i2.7152 
continued to decline significantly. Then, in 2020 the Covid-19 Pandemic national disaster occurred which reduced the productivity of Indonesian people's income. Reporting from Republika, Operations Director of BRI Shariah, Fahmi Subandi said that throughout 2019 BRI Shariah focused on improving the company's fundamental performance. According to him, the company's fundamental factors are one of the factors causing the low price and value of BRI Shariah shares (Puspaningtyas, 2019).

In the market mechanism, prices are determined based on the supply and demand that appears. Likewise with stock prices in the secondary market. Many things affect the supply and demand for shares to form the price of a share in the stock market. There are factors that come from outside and within the company. Factors that come from within and from within are factors that are related to company performance, usually seen from the financial performance as reflected in financial reports, that can be controlled by the company's management. For example, management performance in the company, all the possibilities or expectations in the future, the number of dividends paid, debt and equity ratios, profitability, and other financial ratios.
Various types of financial ratios are one of the most basic considerations used to estimate stock prices. Financial ratio analysis is a way for a company to analyze financial performance assessments that depart from the comparative data of each item in the financial statements. The materials used in this research are Return On Equity (ROE), firm size, and Financing to Deposit Ratio (FDR) as variables that are predicted to affect the stock fluctuation of PT. BRI Shariah TBK throughout the years 2019-2020.

According to Harahap (2007), Return On Equity (ROE) is used as an element to determine the number of return on the investment made by investors. Thus, it can be seen the performance of management in using investments from investors. Harahap (2007), emphasizes that ROE has a positive relationship with share prices. High ROE number will increase the price of share. This is because high ROE gives hope of the high rate of return that investors will get.

Many previous studies have proven and refuted this theory. Such as Satria (2020) shows that ROE does not have a significant impact on the share price of PT BNI (Persero). Furthermore, Yudistira \& Adiputra (2020) shows that ROE has a negative and significant impact on stock prices in the banking subsector listed on the IDX. 
Firm size is a representation of the size of a company by measuring the company's total activities or assets by utilizing the results of the calculation of the logarithmic value of total activities (Hartono, 2008). Riyanto (2010), also states that the size of the company is getting bigger and is closely related to the funding decision or capital structure that a company will implement to optimize its share price or company value.

Trisnasari \& Kardinal (2020) also shows that stock prices are not influenced by company size. Therefore, company size does not guarantee whether a company has a good value or not. However, the finding of Arifin \& Agustami (2016) shows otherwise, where company size has a significant effect on stock prices.

FDR (Financing to Deposit Ratio) describes the total financing channeled by banks against third-party funds collected by the bank. High FDR ratio indicates low liquidity capacity of a bank because it means many outside funds and at least third party funds remaining in the bank (Almunawwaroh \& Marliana, 2018). Research conducted by Warsiati \& Rosalina, (2019) LDR has a significant negative effect on stock prices. Then the research of Wulansari \& Prihantoro (2018) shows that the relationship between LDR and stock prices is negative, but the effect is not significant. Then Ratnasih \& Purbayani's research (2018) shows that LDR has a positive and significant effect on the stock price of PT BNI (Persero).
Referring to the theory and several previous studies which serve as a frame of reference, it can be seen that there are still inconsistencies between theory and research, as well as between research with the same object, namely banking. PT. BRI Shariah, which just conducted its IPO on May 9, 2018, has impressive stock transactions with fluctuating share prices. Therefore, this paper analyzes further related to the effect of ROE, company size, and FDR which affect the share price of BRI Shariah, Tbk. in 2019 and 2020.

\section{Discussion}

\section{A. Literature Review}

\section{Stock Price}

The stock price according to Husnan (2005) is the price spent on proof of ownership of companies listed on the capital market. Then another opinion states "share price is the value of shares that occur as a result of the sale and purchase of these shares on the secondary market" (Sutrisno, 2005). According to Tandelilin (2017), a company's stock price is reflected in its closing price. The closing price is considered the market price because it is the price at the end of the trading day requested by the seller or buyer.

Stock prices are influenced by many factors. Usman (1990) in his book argues that the stock market price is influenced by three things, namely the basic factors of the 
Dadang Husen Sobana; The Effect Of Return On Assets, Firm Size, And Financing To Deposit Ratio On The..

company, social, economic, technical, and political factors of a country. All factors or one of them form market strength which will result in an increase or decrease in share prices due to stock transactions in the capital market.

\section{Return On Equity (ROE)}

Roni \& Pangestu (2020) said that ROE is a financial ratio used by investors and companies to see how much capital that can generate income or net income. In theory, when the ROE value increases, investors will be interested in investing and speculating that the company's performance is good so that it can guarantee a return on investment and in the end the stock price will also be high.

The theory above is reinforced by Tambunan (2007), he states that ROE is used to determine the rate of return (rate of return) of equity. Shareholders and securities analysts pay close attention to this ratio, because the higher the ROE a company produces, the higher its share price.

Kasmir (2010) explains that the formula used to determine Return On Equity (ROE) is as follows:

$$
\begin{aligned}
& \text { ROE } \\
& =\frac{\text { EAT (Earning After Tax) }}{\text { Equity }} \times 100 \%
\end{aligned}
$$

H1: ROE affect stock prices PT. BRI Sharia Tbk

\section{Firm Size}

Company size is something that measures the product of an organization and its service demands (Torang J.E, 2012). Company size shows the value of company size (Annisa, 2008). There are three types of company sizes based on wealth, namely large, medium, and small scale. This is because company size at each scale can be grouped into company size using various methods, including stock market value, a number of activities, log size, and so on (Isbanah, 2015). It is a reflection of the company's ability to have large total assets. Company size is an aspect that measures the demand for an organization's products and services (Torang J.E, 2012). Company size is what defines the size of the company (Annisa, 2008).

H2: Firm size affects the stock price of PT. BRI Sharia Tbk

\section{Financing to Deposit Ratio (FDR)}

Financing to Deposit Ratio (FDR) is one of the liquidity ratios of Islamic banks which is used to find out how much fees are disbursed by Islamic banks from the proceeds of third party funds at the bank. This ratio also assesses the bank's ability to repay third-party funds used from the rate of return on financing.

If Islamic banks channel all of these third party funds in the form of financing, it is likely that they will provide the same 
amount of profit and loss, because the rate of return on financing cannot be ascertained. However, with regard to risks, if the owner of the funds wants to withdraw funds and the bank is unable to fulfill it because of the lack of smooth return of financing, it will be detrimental to the owner of the funds. Therefore, a high FDR ratio will endanger bank liquidity, however, a low FDR ratio also makes banks unproductive in managing their funds (Almunawwaroh \& Marliana, 2018).

In relation to the stock price, this ratio can be a reference for investors in liquidity. Investors can see the bank's ability to guarantee the upper level that is above the investment and the amount of funds available at the bank. However, an FDR ratio that is too high is not good because the FDR is said to be unhealthy in a bank that is associated with 120 percent, and the ratio is said to be 75-80 percent healthy. A good FDR is 75 percent who are in the very healthy category

When the soundness of the FDR is good, it indicates that the funds channeled are quite good and the funds available in the bank are also sufficient to maintain banking liquidity. Thus, investor confidence in this investment will have an impact on increasing demand for shares and automatically share prices will rise.
H3: FDR affects the stock price of PT. BRI Sharia Tbk

\section{B. Research Methods}

\section{Methods and Approaches}

The method used by researchers in conducting this research is descriptive method through a quantitative model approach. As explained by Sugiyono (2010), the quantitative descriptive method describes research data in the form or format of narration, tables and graphics. Meanwhile, Sudjana (2005) states that this quantitative approach is an approach oriented to data analysis in the form of numbers so that it is easier to interpret the results.

\section{Types and Sources of Research Data}

In this research, the type of quantitative data used is numerical data. Where the data is secondary data, which consists of monthly published financial reports of PT. BRI Sharia Tbk and share price data obtained from Yahoo Finance.

\section{Analysis of Data}

The paper analyze the data using the following tests:

\section{Classic Assumption Test}

a. Normality test

the purpose of conducting the normality test according to Ghozali (2016) is to analyze in a regression model whether the confounding or residual variables are normally distributed or not. This is because 
according to Winarno (2015) a data will be said to have a normal distribution if the Jarque-Bera value is less than 2 or the probability value is above 0.05 or a significance level of $5 \%$.

b. Multicollinearity Test

The purpose of conducting the multicollinearity test is to analyze whether the independent variables (independent) in a regression model have a correlation or relationship. Because, a regression model considered to be good if there is no correlation between the independent variables in the regression model (Ghozali, 2016). Decision making based on the VIF value must be $<10$.

\section{c. Heteroscedasticity Test}

This heteroscedasticity means a condition when a factor becomes confounding in a regression model with different variations from one another. To test it, apart from using the graph method, and the heteroscedasticity test of geijser can also be done using the white method. Decision making provided that if the Chisquared probability value of $\mathrm{Obs} * \mathrm{R}$ squared is less than 0.05 , this indicates a heteroscedasticity problem. In fact, if the Chi-squared probability value of Obs * Rsquared is above 0.05 , it means that there is no heteroscedasticity problem (Ratnasih \& Purbayani, 2018).

d. Autocorrelation Test
According to Ratnasih \& Purbayani (2018), autocorrelation is a condition where there is a correlation from the residuals for one observation to another which is arranged according to a time series. To detect the presence or absence of autocorrelation is to use the BreuschGodfrey test or better known as the Lagrange Multiplier (LM) test to detect autocorrelation problems in the regression model, if the probability Chi-squared $\alpha>$ 0.05 . Conversely, if the probability of Chisquared $\alpha>0.05$, there is no autocorrelation problem

2. Multiple Regression Analysis

According to Sudarmanto (2005), regression analysis is a type of parametric analysis that can be used as a basis for predicting and analyzing variants. Some objectives of regression analysis include determining the regression line equation based on the resulting constant and regression coefficient values, to determine the effect of the independent variable and the dependent variable through the t-test, and to test the significance of the independent variable on the dependent variable.

\section{Research Results and Discussion}

\section{Research Result}

\section{Descriptive Analysis}

Descriptive analysis is a data description consisting of the mean, median, 
minimum, maximum, and standard deviation of the research data. The results of descriptive statistics obtained from eviews are as follows:

Tabel 1 Descriptive Statistic

Date: 12/25/20 Time: 20:28

Sample: 2019M01 2020M11

\begin{tabular}{lcccc}
\hline \hline & ROE & SIZE & FDR & STOCK PRICE \\
\hline \hline Mean & 1.594783 & 17.67000 & 107.1122 & 523.0435 \\
Median & 1.130000 & 17.58000 & 114.5800 & 505.0000 \\
Maximum & 4.460000 & 19.74000 & 134.7300 & 1430.000 \\
Minimum & 0.040000 & 17.39000 & 75.26000 & 196.0000 \\
Std. Dev. & 1.246438 & 0.479394 & 23.14119 & 312.4796 \\
Observations & 23 & 23 & 23 & 23 \\
& \multicolumn{2}{c}{ Source: Output results Eviews 9 Output } &
\end{tabular}

The interpretation of the table above is as follows::

a. In the ROE variable, the amount of data is 23 data. From the overall data obtained an average value of 1.594783 . The mean value is 1.13000 , then the highest ROE value is 4.460000 in November 2020, then the lowest ROE value is 0.04000 in January 2019. And the standard deviation of ROE in this study is 1.246428 .

b. In the firm size variable, the amount of data is 23. From the overall data obtained an average value of 17.67000 . The middle value is 17.58000 , then the highest firm size value is 19.74000 in January 2019, then the lowest firm size value is 17.39000 May 2019. And the firm size standard deviation in this study is 0.479394 . c. In the FDR variable, the amount of data is 23 data. From the overall data obtained an average value of 107.1122. The middle value is 114,5800 , then the highest value is FDR 134,7300 in May 2020 , then the lowest value of FDR is 75.26000 in January 2019. And the standard deviation of FDR in this study is 23.14119

d. In the variable stock price, the total data is 23 data. From the total data obtained an average value of 523.0435. The middle value is 505,000 , then the highest stock price value is 1430,000 in November 2020, then the lowest stock price value is 196,000 in March and April 2020. And the standard deviation of stock prices in this study is 312.4796 .

\section{Classical Assumption Analysis}

a. Normality Test 
Dadang Husen Sobana; The Effect Of Return On Assets, Firm Size, And Financing To Deposit Ratio On The..

Based on the results of the histogram test using eviews 9, it is obtained a probability value of 0.673 , this number indicates a greater than 0.05 . Then, the Jarque-Bera number is less than 2, which is
0.791. Thus, it can be concluded that the data are normally distributed and the assumption of normality is fulfilled. The results of the normality test can be seen in the following table.

\section{Picture 1 Normality Test}

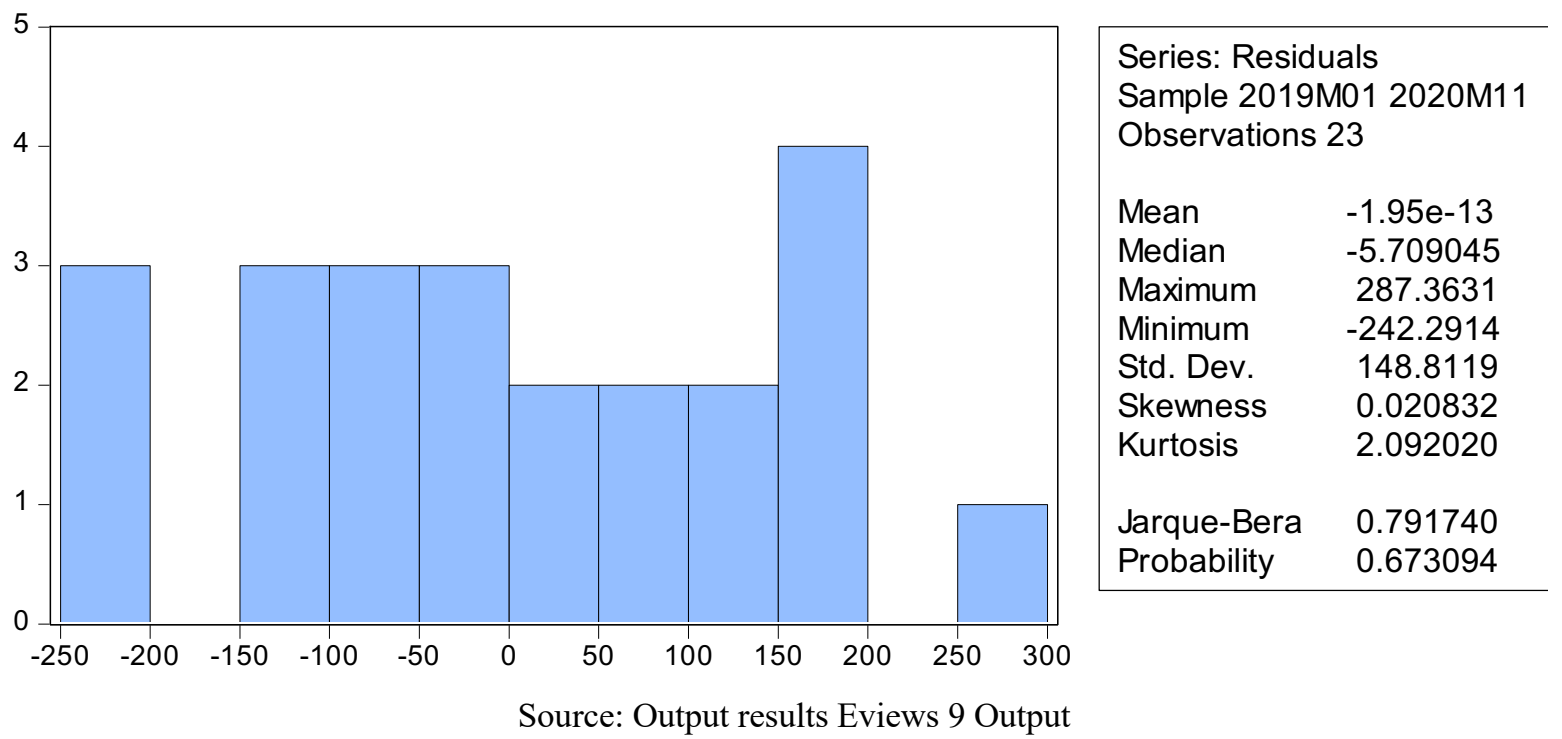

b. Multicollinearity Test

The multicollinearity test results showed that the three independent variables were free of multicollinearity symptoms. In the ROE variable, the VIF result is 1.063 , then the size variable is the VIF result 1.185 and the FDR result is VIF 1.254. All variables have VIF $<10.0$. The summary of the results can be seen in table 2 :

Table 2 Multicollinearity Test Results

Variance Inflation Factors

Date: $12 / 25 / 20$ Time: $20: 24$

Sample: 2019M01 2020M1 1

Included observations: 23

\begin{tabular}{cccc}
\hline \hline & $\begin{array}{c}\text { Coefficient } \\
\text { Variance }\end{array}$ & $\begin{array}{c}\text { Uncentered } \\
\text { VIF }\end{array}$ & $\begin{array}{c}\text { Centered } \\
\text { VIF }\end{array}$ \\
\hline \hline C & 2115106. & 1897.212 & NA \\
ROE & 797.9626 & 2.884069 & 1.063659 \\
SIZE & 6013.401 & 1685.321 & 1.185723 \\
FDR & 2.730289 & 29.35211 & 1.254465 \\
\hline \hline
\end{tabular}

Source: Output results Eviews 9 Output

c. Heteroscedasticity Test 
Based on the test results using Eviews with White's method, it can be seen that the Chi-squared probability value of Obs * Rsquared is 0.6544 , greater than 0.05 . Thus, it can be concluded that the equation regression model does not contain heteroscedasticity problems. The results can be seen in the following table:

Table 3 Heteroscedasticity Test Results

Heteroskedasticity Test: White

\begin{tabular}{llll}
\hline \hline F-statistic & 1.748135 & Prob. F(9,13) & 0.1743 \\
Obs*R-squared & 12.59392 & Prob. Chi-Square(9) & 0.1819 \\
Scaled explained SS & 4.692596 & Prob. Chi-Square(9) & 0.8602 \\
\hline \hline
\end{tabular}

Source: Output results Eviews 9 Output

\section{d. Autocorrelation Test}

Based on the data from the test results in table 4.2 above, where the Chi-squared Probability value is 0.7050 is greater than
0.05. This indicates that the equation's regression model does not contain autocorrelation problems. The calculation results can be seen in table 3 :

Table 4 Autocorrelation Test Results

Breusch-Godfrey Serial Correlation LM Test:

\begin{tabular}{llll}
\hline \hline F-statistic & 1.942568 & Prob. F(2,17) & 0.1739 \\
Obs*R-squared & 4.278551 & Prob. Chi-Square(2) & 0.1177 \\
\hline \hline
\end{tabular}

Source: Output results Eviews 9 Output

\section{Multiple Regression Analysis}

This study uses multiple regression data analysis. Where there is a regression equation, the coefficient of determination, and the results of hypothesis testing in the output eviews. The following is a table of the calculation results

Table 5 Multiple Regression Results

Dependent Variable: STOCK PRICE

Method: Least Squares

Date: 12/25/20 Time: 20:22

Sample: 2019M01 2020M11

Included observations: 23

\begin{tabular}{crlll}
\hline \hline \multicolumn{1}{c}{ Variable } & Coefficient & Std. Error & t-Statistic & Prob. \\
\hline \hline C & 1036.963 & 1454.340 & 0.713013 & 0.4845 \\
ROE & 147.4605 & 28.24823 & 5.220169 & 0.0000 \\
SIZE & 0.878662 & 77.54612 & 0.011331 & 0.9911 \\
FDR & -7.138435 & 1.652359 & -4.320149 & 0.0004 \\
\hline \hline R-squared & 0.773206 & Mean dependent var & 523.0435 \\
Adjusted R-squared & 0.737396 & S.D. dependent var & 312.4796 \\
S.E. of regression & 160.1298 & Akaike info criterion & 13.14662 \\
Sum squared resid & 487189.3 & Schwarz criterion & 13.34409 \\
Log likelihood & -147.1861 & Hannan-Quinn criter. & 13.19628
\end{tabular}


Dadang Husen Sobana; The Effect Of Return On Assets, Firm Size, And Financing To Deposit Ratio On The..

\begin{tabular}{llll} 
F-statistic & 21.59215 & Durbin-Watson stat & 1.220589 \\
Prob(F-statistic) & 0.000002 & \\
\hline \hline
\end{tabular}

Source: Output results Eviews 9 Output

The table above produces the following multiple regression equation:

$$
\begin{gathered}
Y=\alpha+b x+e \\
Y=1036.963+147.4605 \text { ROE } \\
+0.878662 \text { SIZE } \\
-7.138435+e
\end{gathered}
$$

Then the interpretation of the results of the regression equation is

a. The constant value (C) is 1036.963 . This figure means, if the variables ROE, Size, and FDR are fixed or have a value of 0 , it means that the stock price will have a positive value of $1036,963$.

b. The regression coefficient for the ROE variable is positive 147.4605 . This means that for every 1 percent increase in ROE, the stock price will increase by 147.4405 percent, with the prediction of other independent variables being constant or fixed.

c. The regression coefficient for the size variable is positive, namely 0.878662 . This shows a unidirectional relationship between the second variable. If Size has increased by one percent, the stock price will also increase by 0.879 percent.

4. The regression coefficient variable FDR is negative, namely 7.138435 . It shows the opposite relationships between variables. Where if the FDR has decreased by 1 percent, the share price will increase by 7,138 percent. Other variable estimates will have a fixed value.

\section{Hypothesis Testing}

Based on table 5, it is obtained the partial and simultaneous hypothesis test results shown by the results of t-statistics and F-statistics

a. T-test

The $\mathrm{t}$ test aims to see whether the independent variables partially influence the dependent or dependent. Based on the previously built hypothesis, the following are the results of this study.

\section{1) Effect of ROE on Stock Prices}

The t-test results obtained 5.220169 with a significance of 0.000 . That is, the hypothesis is accepted, ROE has a significant positive effect on the share price of PT. BRI Sharia, Tbk for the period 20192020.

\section{2) Effect of Size on Stock Prices}

Based on the statistical test, it was obtained the t-test of 0.011331 with a significance of $0.9911>0.05$. That is, the hypothesis is rejected, company size has no 
effect on the share price of PT. BRI Sharia, Tbk for the period 2019-2020.

3) The Effect of FDR on Stock Prices

Referring to the results of table 5 , it is concluded that the hypothesis is accepted, FDR has a significant effect on the share price of PT. BRI Sharia, Tbk for the period 2019-2020. With the results of the t-test is 4.320149 and a significance of 0.0004 $<0.05$.

\section{b. F-test}

The $\mathrm{F}$ test is carried out to see the simultaneous influence of the ROE, Size, and FDR variables on stock prices. Referring to the results of statistical tests listed in Table 5, the F-statistic results were 21.59215 with a significance of 0.000002 , where the significance was less than 0.05 . Thus the results show that ROE, firm size and FDR have a significant effect on the stock price of PT. BRI Sharia, Tbk for the period 2019-2020.

\section{Analysis of the coefficient of determination}

The coefficient of determination $\mathrm{R} 2$ test is carried out to analyze the ability of a model to explain the relationship between the independent variable and the dependent variable. If you look at the multiple regression results in Table 4, the R-squared result is 0.773206 or 77.3 percent.

This means that ROE, firm size and FDR contribute to the effect of stock prices in this study by 77.3 percent. Meanwhile, the remaining 22.7 percent is influenced by other variables that have not been examined in this study.

\section{Discussion of Research Results}

1. Effect of ROE on the Stock Price of PT. BRI Sharia, Tbk for the period 2019-2020.

In this study, ROE has a positive and significant effect on the share price of PT. BRI Sharia, TBK for the period 2019-2020. Thus, the results of this study are proven to support the theory which states that a high ROE will increase the stock price of PT. BRI Sharia.

This states that the rate of return on investment obtained by investors at PT. BRI Sharia TBK throughout 2019-2020 it is classified as high, so it attracts investors to continue to purchase these shares, which then increases the demand for shares, which affects the level of share prices to increase. So that the quality of the company in managing its equity is quite good.

The results of this study are in line with Rahmani's (2020) research, that ROE has a significant and positive effect on stock prices in banking companies. However, this study is not the same as Nengshy R \& Janrosl's (2020) research, where ROE does not have a significant effect on stock prices in banking institutions. 
In the end, this study arrived at the final finding that, Return On Equity (ROE) at PT. BRI Sharia is high and stable. This was also proven in 2019, PT. BRI Sharia distributes dividends to shareholders as agreed at the Bank's Annual General Meeting of Shareholders. Dividends are set at $10 \%$ of the company's net profit for the 2018 financial year or Rp. 10,659,984,288 and are designated as cash dividends. This is a form of realization of the rate of return on capital that has been invested by investors in PT. BRI Sharia.

Research on the effect of ROE on stock prices has been done by many previous researchers, but what makes the difference is that the object of research used is PT. At that time, BRI Sharia was the first Islamic bank to conduct an IPO. Similar objects were not found in previous studies. Although it has now officially become Bank Sharia Indonesia, PT. BRI Sharia remains the recipient of total capital from the combination of the other two banks, which has a positive impact on the performance of its shares in the capital market. This has become a new spirit for Indonesian Islamic banking to strengthen investment in Islamic shares in the banking sector. So that this research can be a basic reference related to research on the stock price of PT. BRI Sharia that ROE can increase the share price of PT. BRI Sharia.
2. The Effect of Firm Size on the Stock Price of PT. BRI Sharia, Tbk for the period 2019-2020.

Firm size is a description of how big the bank is in terms of total assets. The rarity of research related to the effect of Firm Size on Stock Prices with Islamic or conventional banking objects makes researchers analyze that banks that have large total assets are considered to affect stock prices because they provide certainty for investors in their ability to generate profits. In Islamic banking's asset, the largest portfolio come from financing. So that when the financing and receivables are high, investors will judge the bank as productive and its ability to generate high profits.

But at PT. BRI Sharia TBK the above does not apply. It is proven that the results of statistical tests show that during 20192020 the fluctuation of the share price of PT. BRI Sharia is not influenced by the Firm Size. This shows that investors do not see how the total assets of banks are in investing. The study found that, the total assets do not really reflect the actual condition of the company. In this case, Islamic banks, the amount of financing disbursed does not guarantee the level of return or income from the financing is high because there are financing problems which are still classified as high. 
There is no similar study that conducted research on the effect of firm size on stock prices of banking companies. Thus, this study supports the results of research conducted by Purba et al. (2020) where company size does not have a significant effect on the share price of hotel companies.

However, it is not in line with the research conducted by Novianto (2020) where in his finding shows that company size has an influence on the share price of property companies.

The results of this study related to the effect of company size on stock prices is a differentiator and can be used as a reference for further research. Because this research is different in terms of object, research related to the effect of company size on stock prices has never been studied in banking companies, especially Islamic banking. So this is a new finding, at PT. BRI Sharia, which has the first history as a sharia bank listed on the capital market, does not affect the size of the company's stock price fluctuations.

This shows that the size of the company PT. BRI Sharia, which incidentally is not too big compared to PT. BNI Sharia, does not influence investors to invest. Investors are more concerned with the performance of profits, losses, how big the prospect of taking investment that can happen. So that investors will focus more on the company's fundamental performance as indicated by other financial ratios.

3. The Effect of FDR on the Stock Price of PT. BRI Sharia, Tbk for the period 2019-2020.

Financing to Deposit Ratio (FDR), namely the banking liquidity ratio, which describes the ability of an Islamic bank to disburse third party funds that have been collected in the form of financing. Too high distribution of funds shows that the bank is very productive. This condition reflects that the higher the FDR, the more risky the bank's liquidity is, on the other hand, the lower the FDR indicates the effectiveness of banks in lending.

The results of this study indicate that FDR has a negative and significant effect on the share price of PT. BRI Sharia TBK in the year 2019-2020. This means, when the FDR decreases, it means that the stock price is also predicted to increase, and vice versa.

The study found that, this negative effect was caused by the 2019-2020 monthly FDR of PT. BRI Sharia TBK is in the category of healthy enough to not be healthy. From June 2019 to June 2020, based on the researcher's calculation, the BRI Sharia FDR ratio was above 100 percent, even the highest was in June 2020 
at 134.61 percent. The FDR ratio was quite healthy only in January 2019 with a large 75.26 percent.

This high FDR ratio certainly has a negative effect on stock prices. Because it means, the high amount of funds available in the bank is channeled in the form of financing. Then, an FDR ratio that is too high will cause an imbalance between the amount of financing and the amount of customer deposits or funds, which will have an impact on decreasing liquidity capacity. This is in line with the theory put forward by Husnan (2001) which explains that a change in the composition of debt will have an impact on stock prices.

Therefore, an FDR ratio that is too high causes a high risk for Islamic banks as well. Such as the risk of bad credit, the risk of the ability to repay the customer, and the risk of return on investment by investors. In the end, the bank's performance resulted in decreased profits.

Nugroho \& Rachmaniyah's research (2020) supports the results of this study, where LDR affects the stock price of PT. BRI, TBK. Then, research conducted by Warsiati \& Rosalina (2019) states that LDR has a negative and significant effect on stock prices. And research by Idawati, Pratama, \& Mandasari (2018) shows that LDR has a significant negative effect on the share price of state-owned commercial banks.

Research related to Financing to Deposit Ratio (FDR) in influencing stock prices was not found. Many studies have been conducted on conventional banks which examine the effect of Loan to Deposit Ratio (LDR). The concept of LDR and FDR in conventional banks and Islamic banks is actually the same, it's just that the distribution of financing or credit to conventional banks and Islamic banks is different. In Islamic banks, there are restrictions on businesses that can be given financing, while in conventional banks all types of businesses can be given credit by banks.

So, like the previous two variables, the results of this study are an update for the realm of scientific article research because there has been no previous similar research. So that this can be a frame of reference both in terms of science and for banks in decision-making, because the results obtained by the monthly FDR of PT. BRI Sharia affects stock prices.

\section{Conclusion}

This research results that during 20192020 in the monthly period the share price of PT. BRI Sharia TBK Simultaneously based on the three factors analyzed in this study, namely Return On Equity (ROE), 
Firm Size, and Financing to Deposit Ratio, with an effect of 77.3 percent, and the remaining 22.7 percent indicating other factors outside this study. Meanwhile, only partially ROE and FDR have an effect on the share price of PT. BRI Sharia TBK.

The implication of this research is that PT. BRI Sharia has extraordinary stock potential, first with the current merger decision and BRI Sharia as the recipient of the merger will add assets, add to the market, increase profits in terms of assets or core capital. Then it will also increase investor confidence in stocks. This research can be a frame of reference in the framework, that PT. BRI Sharia, TBK before the merger, its share price was seen by ROE and FDR. That way, BRI Sharia under the name of the merger of Bank Sharia Indonesia can always increase ROE and reduce FDR so that the share price increases and investor confidence increases to buy shares of PT. BRI Sharia TBK.

\section{Bibliography}

Idawati, I. A., Pratama, I. S., \& Mandasari, I. S. (2018). Pengaruh Kinerja Keuangan Terhadap Harga Saham Pada Bank Umum Milik Pemerintah. Jurnal Widya Manajemen Vol. 1, No. 1, 1-17.

Almunawwaroh, M., \& Marliana, R. (2018). Pengaruh CAR, NPF DAN FDR Terhadap Profitabilitas Bank Sharia Di Indonesia. Amwaluna: Jurnal Ekonomi dan Keuangan Sharia Vol. 2 No. 1, 1-18.
Arifin, N. F., \& Agustami, S. (2016). Pengaruh Likuiditas, Solvabilitas, Profitabilitas, Rasio Pasar, dan Ukuran Perusahaan Terhadap Harga Saham Perusahaan Subsektor Perkebunan yang Terdaftar di BEI Periode 2010-2014. Jurnal Riset Akuntansi dan Keuangan, Volume 4, Nomor 3, 1189-1210.

Ghozali, I. (2016). Aplikasi Analisis Multivariate dengan Program IBM SPSS 21. Semarang: Badan Penerbit Universitas Diponegoro.

Harahap, S. S. (2007). Analisis Kritis Atas Laporan Keuangan. Jakarta: PT. Raja Grasindo Persada.

Hartono, J. (2008). Teori Portofolio dan Analisis Investasi. Yogyakarta: BPFE.

Husnan, S. (2005). Dasar-dasar teori Portofolio dan Analisis Sekuritas. Yogyakarta: UPP AMD YKPN.

Kasmir. (2010). Analisis Laporan Keuangan. Jakarta: PT. Raja Grafindo Persada.

Nafiah, R. (2019). Analisis Pengaruh Rasio Keuangan Dan Variabel Makro Ekonomi Terhadap Harga Saham (Studi Kasus Pada Perusahaan Perbankan Yang Masuk Dalam Indeks LQ45). Jurnal Masharif alSharia: Jurnal Ekonomi dan Perbankan Sharia, Volume 4, No. 2, 125-140.

Nengshy R, J. S., \& Janrosl, V. S. (2020). Faktor-Faktor Yang Mempengaruhi Harga Saham Perusahaan Perbankan Yang Terdaftar Di Bursa Efek Indonesia. Jurnal AKRAB JUARA, 25-34.

Novianto, K. P. (2020). Pengaruh Likuiditas, Leverage, Dan Ukuran Perusahaan Terhadap Harga Saham Pada Perusahaan Property And Real Estate Yang Terdaftar Di Bei. Jurnal Ilmu dan Riset Manajemen, Volume 9, Nomor 5, 1-18.

Nugroho, A. Y., \& Rachmaniyah, F. (2020). Pengaruh LDR, NIM, NPL dan BOPO terhadap Harga. Jurnal Komastie Vol 1, No.1, 28-43.

Purba, M. S., Jamaluddin, Pinem, H., \& Sianipar, D. R. (2020). Pengaruh ROE, SIZE, Dan DER TErhadap Harga Saham Pada Perusahaan 
Publik Kategori Restoran, Hotel, Dan Pariwisata. Jurnal Dinamika Ekonomi dan Bisnis, Vol 17 (02), 173-193.

Purwanti. (2020). Pengaruh ROA, ROE, dan NIM terhadap Harga Saham pada Perusahaan Sektor Perbankan yang terdaftar di BEI periode 20152019. Jurnal Aplikasi Manajemen Ekonomi dan Bisnis, Volume 5, Nomor 1, 77-86.

Puspaningtyas, L. (2019). BRI Sharia Fokus Perbaiki Fundamental Perusahaan,

https://www.republika.co.id/berita/ q1iz8q383/bri-Sharia-fokusperbaiki-fundamental-perusahaan, diakses pada 15 Desember 2020

Rahmani, N. A. (2020). Pengaruh Roa (Return On Asset), Roe (Return On Equity), Npm (Net Profit Margin), Gpm (Gross Profit Margin) Dan EPS (Earning Per Share) Terhadap Harga Saham Dan Pertumbuhan Laba Pada Bank Yang Terdaftar Di Bursa Efek Indonesia. HUMAN FALAH: Volume 7. No. 1, 103-116.

Ratnasih, C., \& Purbayani, D. M. (2018). Pengaruh Return On Asset (ROA), Loan To Deposit RatiO (LDR), Dan Capital Adequancy Ratio (CAR) Terhadap Harga Saham Pada. JURNAL MANAJEMEN, Vol. 06. No. 2, 1-16.

Riyanto, B. (2010). Dasar-dasar Pembelanjaan Perusahaan. Yogyakarta: BPFE.

Roni, \& Pangestu, D. (2020). Pengaruh Return On Equity(ROE) Dan Earning Per Share (EPS) Terhadap Harga Saham. Journal of Accounting and Finance (JACFIN), Volume 1, No. 1, 30-36.

Satria, R. (2020). Pengaruh Return On Equity Dan Earning Per Share Terhadap Harga Saham Pada Pt Bank Negara Indonesia (Persero) Tbk Periode 2009-2017. Jurnal Ilmiah Feasible, Vol.2 No.2 , 2042016.

Sudarmanto, G. (2005). Analisi Regresi Linear Ganda dengan SPSS. Yogyakarta: Graha Ilmu.
Sutrisno. (2005). Manajemen Keuangan: Teori Konsep dan Aplikasi. Yogyakarta: Ekonisia.

Tambunan, A. (2007). Menilai Harga Wajar Saham. Jakarta: PT Grasindo.

Tandelilin , E. (2017). Pasar Modal Manajemen Portofolio dan Investasi. Yogyakarta: PT. Kanisius.

Trisnasari, T., \& Kardinal. (2020). Pengaruh Struktur Modal, Ukuran Perusahaan, Likuiditas, dan Profitabilitas Terhadap Harga Saham Sektor Property Pada Holdings Company di Kuala Lumpur Stock Exchange periode 2012-2016. Jurnal Ilmu dan Riset Manajemen, Volume 9, Nomor 5, 113.

Usman, M. (1990). ABC Pasar Modal Indonesia. Jakarta: Ikatan Sarjana Ekonomi Indonesia.

Warsiati, W., \& Rosalina, R. R. (2019). Pengaruh Capital Adequacy Ratio (CAR), Loan To Deposit Ratio (LDR) Dan Return On Assetss (ROA) Terhadap Harga Saham. JURNAL INDONESIA MEMBANGUN, Vol. 18, No. 1., 4558.

Winarno, W. W. (2015). Analisis Ekonometrika dan Statistika dengan Eviews. Yogyakarta: UPP STIM YKP.

Wulansari, D., \& Prihantoro. (2018). Pengaruh Kinerja Keuangan Terhadap Harga Saham Yang Terdaftar Di Bursa Efek Indonesia. Jurnal Ilmiah Ekonomi Bisnis Volume 23 No.1, 1-17.

Yudistira, E. R., \& Adiputra, I. P. (2020). Pengaruh Faktor Internal dan Ekternal Terhadap Harga Saham. Jurnal Ilmiah Akuntansi dan Humanika, Vol. 10 No. 2, 176-184. 